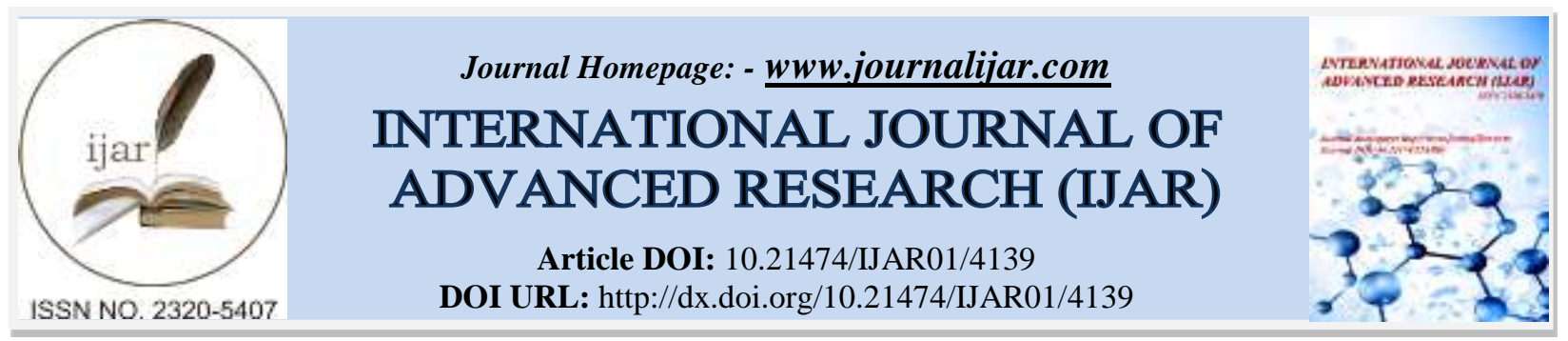

RESEARCH ARTICLE

\title{
EFFECT OF COMPENSATION AND JOB INSECURITY ON EMPLOYEE ENGAGEMENT (STUDY ON EMPLOYEE OF BUSINESS COMPETITION SUPERVISORY COMMISSION SECRETARIAT).
}

\author{
Setyo Riyanto ${ }^{1}$, Ahmad Pratomo ${ }^{2}$ and Hapzi $\mathrm{Ali}^{3}$. \\ 1. Lecturer of Post Graduate, Mercu Buana University, Jakarta Indonesia. \\ 2. Senior Staff at Komisi Pengawas Persaingan Usaha (KPPU), Jakarta Indonesia. \\ 3. Professor of Post Graduate, Mercu Buana University, Jakarta Indonesia.
}

\section{Manuscript Info}

Manuscript History

Received: 09 March 2017

Final Accepted: 04 April 2017

Published: May 2017

Key words:-

Compensation, Job Insecurity, Employee

Engagement, Effect.

\section{Abstract}

KPPU's Secretariat needs employees with high engagement rate to support it's duties and tasks. Employee with high engagement rate will try contribute positively to organizational performance. Employee Engagement can be affected by variables in the employee's workplace. This study aims to analyze the effect of Compensation and Job Insecurity on the Employee Engagement. Data that use in this research is primary data and secondary data. Sampling method used was convenient sampling. From a population of 329 employees of KPPU's Secretariat, 80 employees was picked to be respondent. The method of analysis used in this study is multiple linear regression. Results showed Compensation partially has not significant effect to the Employee Engagement, while Job Insecurity partially has significant effect to the Employee Engagement. On the other hand, Compensation and Job Insecurity simultaneously are having significant effect to the Employee Engagement.

Copy Right, IJAR, 2016,. All rights reserved.

\section{Introduction:-}

In Indonesia, some of the functions of human resource management in the government / public have been regulated. Starting from the process of recruitment, staffing, performance appraisal and compensation system set up in line with the movement of bureaucratic reform. The concept of compensation includes a fairly developed part of the implementation of human resource management because quite a lot of evidence that either indirectly or indirectly, shows the relationship between compensation and other variables in the context of efforts to bolster the performance of companies / agencies. In the scope of government agencies, system improvement schemes on compensation already begun to happen in the teaching profession, law enforcement, as well as employees in other government agencies such as the ministries. In fact, the amount of remuneration, can compete competitively with the compensation of employees in the private sector.

However, not all public agencies / governments managed to make improvements in the area of compensation. In addition to compensation, an improvement over the insecurity of work (job insecurity) in the earlier study still became one of the problems in relation to the efforts to increase employee engagement in government agencies. This condition can be caused by several things such as administrative unpreparedness, disharmony between some of the 
rules, the status quo, as well as understanding uneven. Conditions employees become less tied to the agency indicated in a negative attitude both in the form of talks on the institution where the work or in the form acts as lazy in doing the work, turnover intention, to resign in the form submission by employees concerned.

Business Competition Supervisory Commission (KPPU), one of the government agencies, which is a non-structural established by the Government to be able to act independently (free from intervention of both the government and businesses), execute the mandate of Act No. 5 of 1999, to oversee business activities in Indonesia that can compete with the healthy and free of fraud. The Commission in performing its duties and functions, requires SDM to engage with agencies that are expected to further support the implementation of tasks, functions and authority of the agency. As one of the government agencies KPPU is still experiencing quite a lot of human resources issues.

Since 2010, the number of permanent employees who resign Commission, reached 196 people, (data staffing October, the HRD Section, 2014). This condition is analogous to the phenomenon of the iceberg, because quite a lot of employees that apply to other agencies or companies, but did not pass as well as other reasons, so that some of those who have the intention to transfer for another company (turnover intention) or resign. It is real and can be seen openly in informal conversations that occur in the office environment. Into something that is not common to the majority of KPPU if it does not propose / submit an application while it is opening of jobs both in SOE's or civil servant. Resignation or removal of employees even occur when one employee is still in a period of a bond, wherein if the employee has resigned in that time period, it is required to pay a sum of money as fine a bond. Amount of fines varies, ranging from Rp. 5 million to Rp. 67 million. Fines amounting to tens of millions were not able to deter some employees to submit resignation as an employee of KPPU.

In terms of the application of the compensation, it has not been applied properly and still quite far from the condition of best practice. This is because there are some rules relating to the Commission, the rules relating to the management of state finances, and regulations related to government agencies as well as state officials, that are not harmonious. In terms of earnings and career, conditions in the Commission can be considered still be competitive when compared with the minimal wages in Jakarta as well as when compared with the salaries of civil servants. However, earnings were used as the comparison is not only limited to Jakarta minimal wages and salaries of civil servants alone. When compared with similar income levels in the agency is, as in the Corruption Eradication Commission (KPK), there is a considerable margin, so that the amount of earnings at the Commission looks less competitive. In addition, based on a survey ever undertaken by the Commission in cooperation with the Australia Indonesia Partnership for Economic Governance (AIPEG) 2014 regarding employee satisfaction, which one of finding the weak points in the Commission's HR policies regarding compensation.

Status of the Commission as a permanent employee of the commission, felt less secure (insecure) in terms of the clarity of their employment status. It is generally known that in Indonesia there are several kinds of employment status, such as Civil Servants (PNS), permanent employees, private employees, and employees of state-owned enterprises. Based on survey ever conducted in 2009 by the unit that handles human resources management to obtain an overview of the options / preferences of staff to the employment status, the result that as many as $68.04 \%$ Employees Commission wants civil servant status. Insecurity condition is also exacerbated by the enactment of Law No. 5 of 2014 concerning the State Civil Apparatus, where the status of the Commission's position and other similar government agencies increasingly unclear. In Chapter III, Article 6 of the Act states that an employee ASN (State Civil Apparatus) consists of civil servants (Civil Service) and first aid (Government Employees to Work Agreement). By knowing these facts, staff often expressed a desire for clarity of their status in various forums and behavioral changes are visible through the observation of becoming reluctant to contribute more to the agency.

Given that the tasks and functions carried out by KPPU strategic impact on the Indonesian economy, and no institution / other institutions in Indonesia who carry out the functions similar to those run by KPPU, it becomes interesting to be the object of research. Moreover, the President of the Republic of Indonesia, through Presidential Decree No. 2 of 2015 on the National Medium Term Development Plan 2015-2019 has mandated the KPPU to also oversee the direction of government policy, notably by strengthening investments, increasing healthy competition through prevention and enforcement of competition law in order to create economic institutions that support the climate of healthy competition, restructuring the market structure and the strengthening of the national logistics system that aims to create efficiency with justice. Research will be conducted based on the findings of problems in the field, namely regarding Effect Compensation and Employee Engagement Against Job Insecurity in the of KPPU Secretariat.. 


\section{Literature Review And Hypothesis:-}

Compensation: Forms of payment / payment can be categorized as total compensation and relational returns (Milkovich, Newman, Gerhart, 2014: 13), while the more transactional total compensation, which includes payments received as a direct and indirect cash money as benefit-benefit.

\section{Cash Compensation has the following Dimensions:-}

Base:-

basic salary Is cash compensation that employers pay for work that has been done (by employees). Basic salary has a tendency to reflect the value of the work or skills and generally ignores the distinction atrubut on individual employees.

\section{Merit Pay/ Cost-of-Living Adjustments:-}

Periodic adjustment of the base salary may be made based on changes to another employer pay for the same work, peruahan in the average cost of living, or a change in experience or skill.

\section{Incentives:-}

Incentives different to merit adjusments, where incentives do not increase the base salary and should be recovered each payment period. In addition, the potential size of the incentive payment will generally be known in advance. Incentives can be included in the performance of individual employees, teams of employees, total business unit, or some combination of individual, team and unit.

\section{Long-Term Incentives:-}

Long-Term Incentives employee intended to focus efforts on the results in a few years.

Benefits have dimensions:

\section{Income Protection:-}

Health insurance, pension plans, life insurance and savings plans are common benefits.

\section{Work/Life Balance:-}

Programs that help employees integrate work and responsibility for their personal lives better, including time off from work, access to services / services to meet specific needs (counseling pharmaceuticals, financial planning), and setting flexible job (telecommuting, schedule non-traditional work).

\section{Allowances:-}

Allowances often grow out of any condition of supply shortages. For example, if in a region / country rice supply shortage, then the allowances in the form of rice was made possible.

\section{Job Insecurity:-}

Employees experiencing Job Insecurity has doubts whether he/she will be retained to work or will lose their jobs. As for the things they do is they take steps to get out of the company to find another job to make sure. Therefore, those who are in the job insecuriy can not prepare for their future. As for the aspect of Job Insecurity by Greenhalgh and Rosenblatt (1984) in Maulana (2012: 8) explains that Job Insecurity consists of two aspects, namely the threat of losing their jobs and aspects of the threat of losing an important asset of work, such as salaries, opportunities for promotion, and other etc.

Based on these two aspects, Ashford, Lee, and Bobko (1989) in Maulana (2012: 9) to develop the components of job insecurity became severity of the threat and helplessness. Severity of the threat in question is how much people perceive a threat to the aspects of the job and the threat to jobs overall. Threats to aspects of the work include opportunities for promotion, the freedom to make a schedule, and others. A person's perception of the magnitude of the threat aspects of work can be seen by how big those aspects considered important and how likely an individual will lose these aspects.

\section{Employee Engagement:-}

Employee Engagement is a measure of the level of emotional attachment to both positive and negative to work, friends and their organizations that affect the desire to learn and the performance of that worker to their job Scarlett in Gujral, (2013: 21). According to Gibbons in Nusatria and Suharnomo, (2011: 6) employee engagement is the 
relationship of emotional and intellectual owned by employees to their work, organization, manager or co-workers who give effect to add discreationary effort in his work. A good relationship with the work which they are responsible, the organization where he works, the manager who became her supervisor and provide support and advice, or colleagues who support each other to make an individual can give the best effort that exceeds the requirements of a job. Harter et al. (2002) in Albdour and Altarawneh (2014) argued that employee engagement is important to the outcome of significant business and performance in many organizations. Based on the definition of employee engagement by Schaufeli et al (2005) in Maulana (2012), the dimensions of employee engagement are:

Vigor:-

Vigor is a state filled with high energy level and mental tough in doing the job. Employees with high vigor that would have a high desire to invest effort in one job. They will survive despite facing difficulties in employment.

\title{
Dedication:-
}

Dedication is characterized by a significant feeling, enthusiasm, inspiration, pride, and challenged. Employees who have significant feelings are employees that have significance for the existence itself in the work. The feeling is perasaanyang attentive enthusiasm and interest in doing the job. They feel inspired to do the work, proud and challenged.

\begin{abstract}
Absorption:-
Absorption is giving full attention to the job and is involved in a job. Those who have absorption in the work are those who feel that the time passed so quickly. They are difficult to separate from his work.

\section{Relation between compensation with Employee Engagement:-}

Compensation that is considered comparable to what is done by employees, may affect the willingness of employees to do more for the company / institution. This condition can describe the level of employee engagement are simple. A humane conditions, where as humans tend to compare what is obtained by what is done. When there is a gap that is considered to be detrimental to a particular person from an activity that is done, then people tend not to continue or even reduce the intensity of the activity.
\end{abstract}

\section{Relation between Job Insecurity with Employee Engagement:-}

De Cuyper and De Witte (2005) in Maulana (2012) explains that there is a negative correlation between Job Insecurity and employee engagement. From the research results they obtained the data that Job Insecurity on temporary contract workers steeper than Job Insecurity in the permanent work force. In conditions of employment are relatively less stable (insecure) both in terms of employment status, contractual or non-contractual, can cause concern for the continuation of a person working in a particular institution. Such concerns are high or low impact on Job Insecurity of that worker.

\section{Relations between Compensation and Job Insecurity with Employee Engagement:-}

In circumstances where compensation with employment status clear to employees perceived by the employee, commensurate with the performance they had produced to the company / agency or even exceeds what is expected, then the employee may comment positively about how the company / institution treats the employee with good colleagues or stakeholders.

In addition, the employee will tend to be more comfortable to work in companies / agencies than to seek employment elsewhere. More vigorous efforts can also be shown by the employee, to support the performance of the company / institution. 
In the model, the relationship of independent variables and the dependent variable can be shown as follows:-

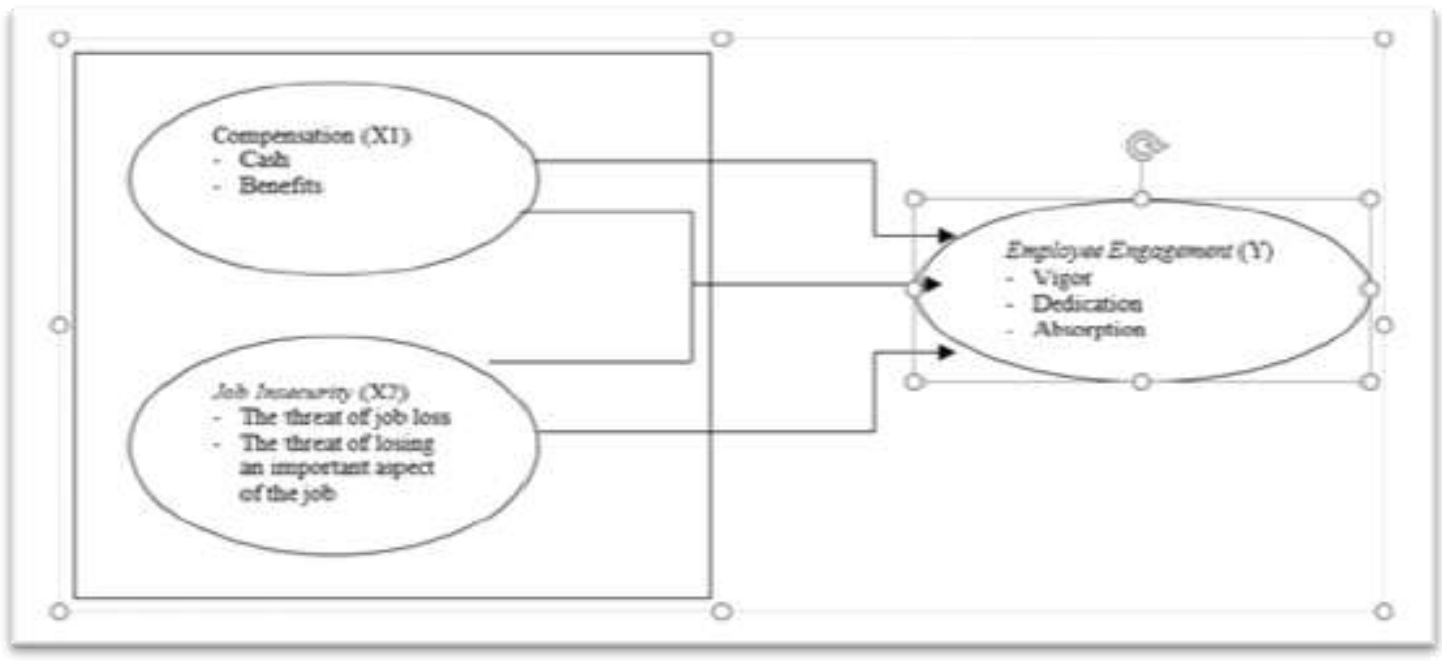

Image 1:- Framework

Research Hypothesis: 1) Compensation affects employee engagement; 2) Job insecurity affects employee engagement; and 3) Compensation and job insecurity affects employee engagement.

\section{Research Method:-}

The population of this study were employees of the Business Competition Supervisory Commission as many as 329 people. To determine the size of the study sample, we can choose from several available formulas. The size of the samples obtained from the formula for determining the sample size is only a guideline, not an absolute requirement Sclesselman, (1982) in Agung (2004: 114). To determine the sample size of the population, the researcher used a formula from Slovin, Consuelo (1993) in Januarto (2014: 26):

$\mathrm{n}=$ the sample size

$\mathrm{N}=$ population size

$\mathrm{E}=$ the critical value (limits of accuracy) is desired. Researchers determined by $10 \%$. then:

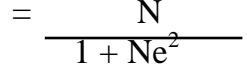

$\mathrm{n}$

$$
\begin{aligned}
& =\frac{329}{1+329(10 \%)^{2}} \\
& =\quad 76,68 \text { rounded up to } 80 \text { people }
\end{aligned}
$$

In determining the amount of the standard error of $10 \%$ influenced by the number of potential respondents who may be obtained from the existing population, where there are pros and cons in the conditions of internal Secretariat of the Commission which led to the group of clerks who do not support their internal research involving the Commission's secretariat. If using a smaller standard error (eg 5\%), then the total sample of respondents will increase. It is feared that the researchers failed to get the number of potential respondents were pro with this study. These conditions also impact on the selection of sampling methods used in this study, which is a non-probability sampling with convenient sampling technique. The use of this technique is expected to adapt easier to find potential respondents with a sufficient amount so that primary data collection is not inhibited (Setyo, 2002: 161). In addition to the convenient sampling technique only requires a low cost and also saves time, Malhotra (2007: 85).

\section{Test Reliability and Validity:-}

Reliability test is performed to measure the consistency of the measurement results when the measurement was repeated. Reliability testing with reference to the alpha coefficient or Cronbach's alpha. Reliability is considered good if the value of Cronbach's alpha> 0.6 (Malhotra, 2007: 92).

Alpha formula is as follows: 


$$
\mathrm{r}_{11}=\frac{k}{k-1}\left(1-\frac{\sum S i}{S t}\right)
$$

Description :

r11 = coefficient of instrument reliability (Cronbach alpha)

$\mathrm{k}=$ the number of questions

$\Sigma \mathrm{Si}=$ Total variance score each question

$\mathrm{St}=$ total number of variants.

The data have been obtained by the researchers will further analyze its validity. This analysis aims to determine whether an instrument measuring instrument has been carrying out its functions. Validity relates to a match between a construct and indicators used to measure it. A measurement scale is valid if it does what it should do and measure what should be measured (Wijaya, 2009: 34).

\section{Classical Assumption Test:-}

To get results of regression tests that are BLUE (Best Linear Unbiased Estimator), it must be through a classic assumption test including normality test, multicollinearity test, heteroscedasticity test. Normality test is done to see if the independent variables and the dependent variables included in the regression model will have a normal distribution or not. A good regression model is data distribution to normal or near normal. To test the normal distribution with a view of data dissemination (point) on the diagonal axis of the graph. If the data is spread around the diagonal line, the regression model to meet the assumption of normality. And if the data is spread far from the diagonal line and did not follow directions or diagonal line, the regression model did not meet the assumption of normality. Multicolinearity test is a test intended to test whether the regression model later found a correlation between the independent variables. A good regression model was not contains multicollinearity (Wijaya, 2009: 43). To detect the presence of multicollinearity, can refer to the VIF. If the value of the independent variable VIF $<10$, then multicolinearity tolerable level.

Heteroscedasticity indicates that the variable is not the same variance for all observations. A good regression model actually have the same variance in each observation, also called homoskedasticity. According to Santoso (2000: 52), to determine a regression model has no symptoms Heteroscedasticity is with reference to the level of significance of the Spearman rank correlation coefficient of all variables independent the residual variable is greater than 0.05 .

\section{Test Multiple Linear Regression:-}

Regression analysis is a statistical procedure for analyzing the effect of independent variables on the dependent variable. In this study, the independent variable is the Compensation and Job Insecurity. While the dependent variable is employee engagement. In multiple linear regression, has a number of independent variables is more than one. In multiple linear regression tests include some specific tests, including tests of multiple determination coefficient $\left(\mathrm{R}^{2}\right)$, simultaneous test ( $\mathrm{F}$ test), and the partial test ( $\mathrm{t}$ test).

\section{Dimensional Analysis:-}

Analysis dimensions are used to test the correlation of the most powerful influence on the variable dimension of training, remuneration and career path to employee performance. The strongest correlation dimension can be seen from the Pearson correlation is greatest. It required dimensions of the correlation matrix between the independent variables (X1 and $\mathrm{X} 2)$ and the dimensions of the dependent variable (Y).

\section{Result and Discussion:}

Characteristics of Respondents:

Based on data and respondents in the questionnaires, data on the characteristics by gender and tenure.

\section{Based on Gender:}

The number of respondents can be seen in Table 1 Gender below, that the number of female respondents ie $66.3 \%$ more. The results of the analysis of the data by gender are presented Table 1 below: 
Table 1:- Distribution of Respondents by Gender

\begin{tabular}{|c|c|c|}
\hline & Total & Percent \\
\hline Male & 27 & 33.8 \\
\hline Female & 53 & 66.3 \\
\hline Total & 80 & 100.0 \\
\hline
\end{tabular}

Source: The results of data processing SPSS 20 (2015).

Based on information from the Employee Welfare Section, Secretariat of the Business Competition Supervisory Commission, this condition is one of the effects of recruitment patterns that have been made in which the decision to recruit more focused on the value of the test / score them without considering the composition of men and women. From recruitment ever conducted, the majority of women have a value / high score. Gender so that women become the majority received as clerks of KPPU Secretariat.

Based Work Period: The results of an analysis of the working lives of the respondents can be seen in Table 2 below.

Table 2:- Respondent Characteristics Based on Tenure.

\begin{tabular}{|c|c|c|}
\hline & Total & Percent \\
\hline Less than 5 years & 38 & 47.5 \\
\hline 5 to 10 years & 40 & 50.0 \\
\hline More than 10 years & 2 & 2.5 \\
\hline Total & 80 & 100.0 \\
\hline
\end{tabular}

Source: The results of data processing SPSS 20 (2015)

Based on the data in Table 2 shows that most respondents (40 people) have a service period of 5 to 10 years or $50 \%$ of total respondents. This condition occurs as a result of sufficient number of employees who filed resign with tenure of less than 5 years, while employees with tenure of 5 to 10 years is quite difficult when looking for another job because of the age limit had passed the general requirements set by several agencies / enterprise and competence of the employees become increasingly specialized in the field of business competition which is not the taste of the general labor market.

\section{Data Analysis:}

Before analyzing the hypothesis, first testing the validity, reliability and classical assumption of research data by using tools SPSS version 20. The statements contained in the questionnaire for variable compensation $\left(\mathrm{X}_{1}\right)$, Job Insecurity $\left(\mathrm{X}_{2}\right)$, and Employee Engagement $(\mathrm{Y})$ are arranged in such a way so as to provide input of data to the writer. Beads prepared statement and was measured in Likert Scale in which the statements are displayed in numeric form which has a weighting 1-6.

Validity and reliability testing is a process for test grains statements contained in a questionnaire whether the contents of grains such statements are valid and reliable. If grains such statements are valid and reliable then it can be used to measure the factors. But before the data are ordinal can be tested, first needs to be converted so that data into a character interval. The software used for the conversion process is Method of Successive Interval (MSI)

In this study conducted to test the validity of research instrument variables $X_{1}, X_{2}$, and $Y$ with SPSS Ver. 20. The basis for a decision are:

1. If $r$ count $>r$ table then the statement is valid.

2. If the count $r<r$ table then the statement is not valid.

$\mathrm{R}$ count value obtained from the calculation using SPSS software and formulas that have been determined while the value of $\mathrm{r}$ table obtained from table $\mathrm{r}$-product moment with significance level of 5\%. The validity of the test is the test of research instruments, whether the grains statements contained in the research instrument is valid or not. Beads of this statement is made based on the indicators listed in the table of operational variables and indicators are based on the dimensions and variables studied. In this testing phase research instruments deployed to several respondents in advance as much as 80 respondents. 
when a significance level of $5 \%$ and the number of respondents 80 people $(\mathrm{N})$ the obtained value of $\mathrm{r}$ table $=0.220$ for all independent and dependent variables. While the value of $r$ count obtained from the calculation results are shown in the table below. Terms of validity is to compare $r$ value (corrected item total correlation of the results if the SPSS) with $r$ table $(0.220)$, then the validity criteria in this study are:

1. If $r$ count positive, and $r$ count $>0.220$ ( $r$ table), then the item or variable is valid.

2. If $\mathrm{r}$ count not positive, and $\mathrm{r}$ count $<0.220$ ( $\mathrm{r}$ table), then the item or the variable is not valid.

After all point statement declared invalid then the next test is to test the reliability of the questionnaire. Reliability testing is related to the problem consistency to the instrument. How to measure the reliability of the most common is to use a coefficient of Cronbach's Alpha or Alpha According to Malhotra (2007: 92), a variable is considered reliable if it had a Cronbach's Alpha> 0.6. This means that if the value of Cronbach's Alpha greater than 0.6 (benchmarks) the instrument is Reliable and vice versa if the Cronbach's Alpha value is smaller than 0.6 the instrument is Not Reliable. In other words, the basis of the decision is as follows:

1. If the Cronbach's Alpha positive or greater than the minimum limit (0.6) the instrument is reliable.

2. If the Alpha Cronbach's negative or smaller than the minimum limit (0.6) the instrument is not reliable.

\section{The Reliability and validity test of the Variable Compensation (11 statements):-}

Based on the results of the processing of SPSS with the Test Statistics Alpha Croncbach's done can be seen that for variable compensation $\left(\mathrm{X}_{1}\right)$ has a value of coefficient Alpha or Alpha Croncbach's of 0.858 and compared with a minimum threshold coefficient alpha predetermined gained $0.858>0.6$, and is therefore concluded that the instrument that has been deployed and will be used for data processing is Reliable.

Table 3:- Validity Test Instruments Variable Compensation (X1)

\begin{tabular}{|c|c|c|c|}
\hline Statement & r count & r table & Validity \\
\cline { 3 - 4 } & & & r count $>$ r table \\
\hline $\mathrm{k} 1$ & 0,755 & 0,220 & Valid \\
\hline $\mathrm{k} 2$ & 0,808 & 0,220 & Valid \\
\hline $\mathrm{k} 3$ & 0,755 & 0,220 & Valid \\
\hline $\mathrm{k} 4$ & 0,620 & 0,220 & Valid \\
\hline $\mathrm{k} 5$ & 0,828 & 0,220 & Valid \\
\hline $\mathrm{k} 6$ & 0,786 & 0,220 & Valid \\
\hline $\mathrm{k} 7$ & 0.433 & 0,220 & Valid \\
\hline $\mathrm{k} 8$ & 0.385 & 0,220 & Valid \\
\hline $\mathrm{k} 9$ & 0.631 & 0,220 & Valid \\
\hline $\mathrm{k} 10$ & 0.718 & 0,220 & Valid \\
\hline $\mathrm{k} 11$ & 0.261 & 0,220 & Valid \\
\hline
\end{tabular}

Source: The results of data processing SPSS 20 (2015)

Variable Remuneration $\left(\mathrm{X}_{2}\right)$ has a coefficient Cronbach's Alpha or Alpha of 0.890 and compared with the minimum limit specified alpha coefficient obtained 0.890> 0.6 can thus be concluded that the instrument has been deployed and will be used for data processing is Reliable. Variables Job Insecurity $\left(\mathrm{X}_{2}\right)$ contained 26 statements, ie statements starting point of ji1 up to number ji26. All statements for variables Job Insecurity $\left(\mathrm{X}_{2}\right)$ declared invalid because it is based on the calculation results SPSS all point statement that there have values of $r$ count $>r$ table.

Test The reliability and validity of Employee Engagement (9 statements):-

Likewise with variable Employee Engagement (Y) has coefficient Cronbach's Alpha or Alpha of 0.915 and compared with the minimum limit specified alpha coefficient obtained $0.915>0.6$, thus it can be concluded that the instrument has been deployed and will be used for data processing is reliable.

Table 4:- Instrument Validity Test of Employee Engagement Variable

\begin{tabular}{|l|l|l|l|}
\hline Statement & r count & r table & Validity \\
\cline { 4 - 4 } & & & r count> $r$ table \\
\hline ee1 & 0,729 & 0,220 & Valid \\
\hline ee2 & 0,848 & 0,220 & Valid \\
\hline ee3 & 0,872 & 0,220 & Valid \\
\hline
\end{tabular}




\begin{tabular}{|l|l|l|l|}
\hline ee4 & 0,728 & 0,220 & Valid \\
\hline ee5 & 0,812 & 0,220 & Valid \\
\hline ee6 & 0,846 & 0,220 & Valid \\
\hline ee7 & 0,777 & 0,220 & Valid \\
\hline ee8 & 0,642 & 0,220 & Valid \\
\hline ee9 & 0,694 & 0,220 & Valid \\
\hline
\end{tabular}

Source: SPSS data processing results (2015)

Variable Employee Engagement (Y) containing 9-point declaration that numbers starting point statement of ee1 until ee9 number. Based on Table 4, it can be seen that all point statement for Employee Engagement variable (Y) is valid because it is based on the calculation of SPSS all point statement that there have values of $r$ count $>r$ table.

\section{Classical Assumption Test:-}

To get results of regression tests that are BLUE (Best Linear Unbiased Estimator), it must be through a classic assumption test including normality test, multicollinearity test, and heteroscedasticity test.

\section{Normality Test:-}

Normality Test results as can be seen in the Figure below that normal probability plot shows that the data points form a linear pattern, so it can be considered to be consistent, with a normal distribution. A good regression model is data distribution to normal or near normal. To test the normal distribution with a view of data dissemination (point) on the diagonal axis of the graph. If the data is spread around the diagonal line, the regression model to meet the assumption of normality. And if the data is spread far from the diagonal line and did not follow directions or diagonal line, the regression model did not meet the assumption of normality.

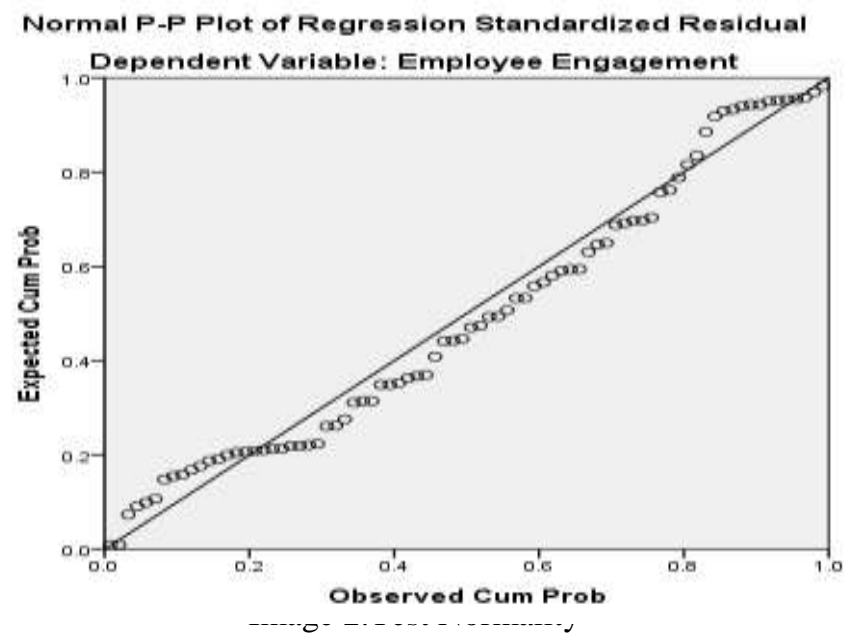

Test Multicollinearity:-

In this multicolinearity test is to determine the extent of the correlation amongst the independent variables. In this test can be seen in table Coefficients results of the regression variables $\mathrm{X}_{1}$ and $\mathrm{X}_{2}$, the $\mathrm{Y}$ (Table 6) seen that VIF respectively by 1,811 and 1,811 where the value of the VIF in turn is under the value of 10 or VIF $<10$ so that this correlation multicollinearity not occur due to the occurrence of multicollinearity if VIF> 10.

Table 5:- Test Multicollinearity.

\begin{tabular}{|l|l|l|l|}
\hline \multicolumn{2}{|l|}{} & Collinearity Statistics \\
\hline \multicolumn{2}{|l|}{ Compensation } & Tolerance & VIF \\
\hline & Job Insecurity & .552 & 1.811 \\
\hline & .552 & 1.811 \\
\hline
\end{tabular}

Source: SPSS data processing results (2015) 


\section{Heteroscedasticity Test:-}

Heteroscedasticity test is used to indicate the presence or absence of classic assumption deviation heteroscedasticity, which is to determine whether or not the relationship between confounding variables with independent variables. One of the ways used to determine whether there is heteroscedasticity is to use graph plots the value attached to the residual. Detection of the presence or absence heteroscedasticity to see whether there is a specific pattern in a scatterplot graph between the bound and residual values, where the axis $\mathrm{Y}$ is the predicted and $\mathrm{X}$ is a residual. If there is a value of a specific pattern, such as dots that form a particular pattern of regular, then the indicate has occurred heteroscedasticity. If there is no clear pattern as well as the points spread above and below the numbers on the $\mathrm{Y}$ axis, then it does not happen heteroscedasticity (Gujarat, 2002: 69). The test results heteroscedasticity with Scatterplot graph showing the results as shown in the following figure.

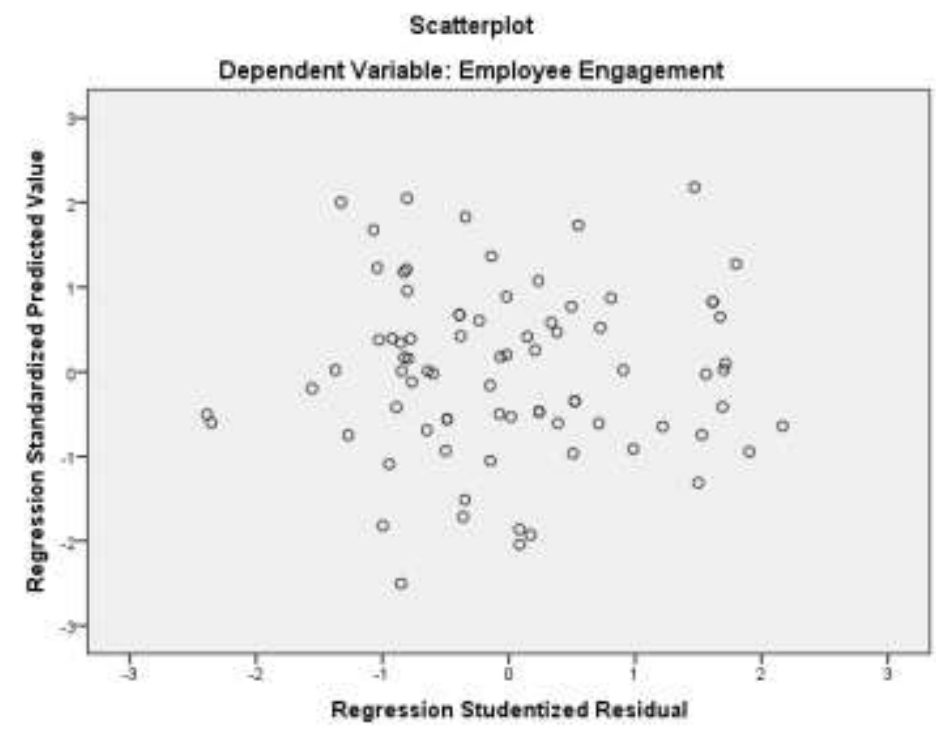

From the picture above it can be seen that heteroscedasticity does not happen because there is no clear pattern as well as the points spread above and below 0 on the $\mathrm{X}$ axis, so that it can be said heteroscedasticity test is met.

\section{Regression Testing:}

This statistic illustrates the regression equation to determine the numerical constant and significant regression coefficients as well as to answer the hypothesis of this study.

\section{Coefficient of Determination Regression Test:}

From the test results of multiple determination coefficient that has been done, indicating the value of $\mathrm{R}$ square of 0.125 , which means that the ability of independent variables to explain the magnitude of the variation in the dependent variable was $12.5 \%$, the rest is explained other variables that are not included in equations or in this study.

Based on the coefficient of determination regression test, there are many other factors that can influence employee work involvement, such as job satisfaction, motivation, leadership style, work discipline, morale and so forth. These other factors also affect employee performance and employee productivity this is based on the results of research from some previous researchers include:

1) Job satisfaction and leadership style have a positive and significant effect on employee productivity either partially or simultaneously at PT. General Insurance Bumiputera Muda 1967 (Margarita Thessa Maida, Setyo Riyanto, Hapzi Ali: 2017);

2) Motivation and job satisfaction have a positive and significant effect on teacher's performance either partially or simultaneously or in this context bias also to employee performance in general in company and other organization. The higher motivation and job satisfaction of employees will have a positive impact on performance (Setyo Riyanto, Adonia, Hapzi Ali: 2017);

3) Work motivation and job satisfaction have positive and significant impact on organizational commitment and impact on employee /employee performance (Masydzulhak, Hapzi Ali, Leni: 2016); and 
4) Work Discipline and Morale have a positive and significant impact on Padang Dua Primary Employee Service Employee Performance, either partially or simultaneously, (Agussalim, Ali Hapzi, et.al: 2016).

\section{Test Unison:}

Then, to determine the significance of the influence of the independent variables together on the dependent variable, then used the F test with a degree of confidence (df) used was 0.05 as shown in the following table:

Table 6:- Test F Compensation and Job Insecurity to Employee Engagement

\begin{tabular}{|l|l|l|}
\hline & F & Sig. \\
\hline Regression & 5.521 & $.006^{\mathrm{b}}$ \\
\hline
\end{tabular}

Source: SPSS data processing results (2015)

From the table values obtained Ftest 5,521 with a probability value $(\mathrm{sig})=0.006$. Value of $F(5,521)>\mathrm{F}$ table $(3.12)$, and sig. less than 0.05 or a value of $0.006<0.05$; then $\mathrm{H}_{0}$ and $\mathrm{H}_{1}$ accepted, meaning Compensation and Job Insecurity together (simultaneously) a significant effect on employee engagement.

Partial Test Effect of Compensation and Job Insecurity against Employee Engagement can be seen in Table 7.

Table 7:- Test Results Effect of Variable Compensation and Job Insecurity Variable Against Employee Engagement

\begin{tabular}{|c|c|c|c|}
\hline Variable & Regression Coefficients & T & Sig. \\
\hline (Constant) & 1.395 & 2.596 & .011 \\
\hline Compensation & -.200 & -1.137 & .259 \\
\hline Job Insecurity & .674 & 3.081 & .003 \\
\hline
\end{tabular}

Source: SPSS data processing results (2015)

According to the table dika inputted into the regression equation, it becomes as follows:

$\mathbf{Y}=\mathbf{a}+\mathbf{b} \mathbf{X}_{1+} \mathbf{c} \mathbf{X}_{2}$

$Y=1,395-0,200 X_{1}+0,674 X_{2}$

\section{Inter-Dimensional Correlation:}

Correlation between dimensions aims to determine the relationship between two variables that do not show the functional relationship (related does not mean due). Correlation test is intended to determine the strongest links on the dimensions of the variable compensation and Job Insecurity with variable dimensions of Employee Engagement. The closeness of this relationship is expressed in the form of the correlation coefficient.

Table 8:- Matrix Correlation Between Dimensions.

\begin{tabular}{|l|l|l|l|l|}
\hline Variable & & \multicolumn{4}{|l|}{ Employee Engagement } \\
\hline \multirow{3}{*}{ Compensation } & Dimensions & Vigor & Dedication & Absorption \\
\hline \multirow{3}{*}{ Job Insecurity } & Cash Compensation & .025 & .048 & $.291^{* * *}$ \\
\cline { 2 - 5 } & Benefits & .117 & .027 & $.237^{*}$ \\
& Threat of Losing a Job & -.085 & -.083 & .107 \\
\cline { 2 - 5 } & $\begin{array}{l}\text { Threats Losing Important } \\
\text { Aspect Of Work }\end{array}$ & $.302^{* *}$ & $.478^{* * *}$ & $.438^{* *}$ \\
\hline
\end{tabular}

Source: the result of a SPSS data (2015).

Correlation between dimensions above show that:

1. For the variable compensation, the dimensions of the most powerful is the dimension related to the dimensions of Cash Compensation Absorption of variable Employee Engagement with coefficient $=0.291$, while a positive sign shows, if the Cash Compensation ride then Absorption will rise and vice versa.

2. For the variable Job Insecurity, the dimension most strongly associated is the dimension of threat Losing Important Aspect of Work towards dimension Dedication of variable Employee Engagement with coefficient = 0.478 , while a positive sign shows, if the threat Losing Important Aspect of Work up then Dedication will rise and otherwise. 


\section{Conclusions:-}

1) Compensation for insignificant / weak against Employee Engagement. However, it was found that the dimensions of Cash Compensation has a strong correlation with the dimensions of Absorption; 2) Job Insecurity variables significantly influence employee engagement. In addition, it was found that the dimensions of threat Losing Important Aspect of The work has a strong correlation with variable dimensions Dedication of Employee Engagement; 3) Compensation and Job Insecurity proven together (simultaneously) a significant effect on employee engagement.

Suggestions:- 1) To improve Employee Engagement from secretariat Staff Business Competition Supervisory Commission, it is important for the leadership of Business Competition Supervisory Commission to focus more on improving their employment status, because of the clarity of their employment status will be able to improve the safety of employees and the impact on the increased engagement of employees; 2) The leadership of the Commission should be in parallel or a combination of continuously working to improve the value of compensation as well as ensuring the employment status of the employee. Dimensions Threat Losing Important Aspect Of Works of variables Job Insecurity has a strong correlation with variable dimensions Dedication of Employee Engagement, then apart from clarity about the promotion, work locations representative; 3) implementable options include conversion mechanism may be through employee status into the Civil Service Commission. These policy options can be taken in coordination with other relevant agencies such as the Ministry of Administrative Reform and Bureaucratic Reform in terms of employment status of an employee and with the Ministry of Law and Human Rights in the case of preparing the legal basis for the policy.

\section{References:-}

1. Asshiddiqie, Jimly. \{2015\} Function Mixed Commission As Quasi Judicial Institutions. www.jimly.com (Accessed on December 19, 2015).

2. Albdour, Abbas, Ali; Iklhas, I, Altarawneh. $\{2014\}$. Employee Engagement and Organizational Commitment: Evidence from Jordan. International Journal of Business, Vol. 19 (2) ISSN: 1083-4346.

3. Ankudinov, B, Andrei; Lebedev, V, Oleg. \{2014\}. Job Insecurity and Employees' Motivation To Engage in Professional Education. American Journal of Applied Sciences, Vol. 11 Issue 5 p 860.

4. Agussalim, Ali Hapzi, et.al, 2016. Analysis Work Discipline and Work Spirit toward Performance of Employees (Case Study Tax Office PratamaTwo Padang). International Economic Research (IJER),ISSN: 0972-9380.www.serialsjournals.com, Index: Scopus Q3, 0.123. No. 13. Issue No. 6, page [2541-2556] .

5. Blyton, Paul; Bacon, Nicolas. \{2001\}. Job Insecurity: A Review of Measurement, Consequences and implications. Human Relations, Vol. 54 no. 9 p 1223-1246.

6. Dessler, Gary. \{2007\}. Human Resource Management Tenth Edition: PT. Index.

7. Farida, Nur, Yusriyati. \{2003\}. Influence and Compensation Job Insecurity on Job Satisfaction. Thesis. Diponegoro University. Semarang.

8. Lawton, D, Eddie; Taye, Fikru; Sergey Ivaanov. $\{2014\}$. Job Insecurity and Other Leadership Issues in Organizations. International Journal of Organizational Innovation, Vol. 7 Issue 2 p 79-86.

9. Marciano, Paul L. $\{2010\}$. Carrots and Sticks Dont Work Build a Culture of Employee Engagement with the Principles of RESPECT. Mexico: McGraw Hill.

10. Margarita Thessa Maida, Setyo Riyanto, Hapzi Ali, 2017. Effect of Job Satisfaction and Leadership Style towards Employee Productivity at PT. Asuransi Umum Bumiputera Muda 1967. Saudi Journal of Business and Management Studies (SJBMS). www.scholarsmepub.com/sjbms, ISSN 2415-6563 (Print), ISSN 2415-6671. DDI:10.21276/sjbms. Volume-2, Issue-3A (March, 2017).

11. Masydzulhak, Hapzi Ali, Leni, 2016. The Influence of Work Motivation and Job Satisfaction on Employee Performance and Organizational Commitment as an Satisfaction as an Intervening Variable, in PT. Asian Isuzu Casting Center. Quest Journal of Research in Business and Management (QUEST-JBM).ISSN (Online): 23473002.www.questjournals.org.Vol.4, Issue10, 2016, page[01-10].

12. Maulana, Sischa. \{2012\}. Relationship Between Job Insecurity and Work Engagement In Lecturer Non-Civil Servant (PNS), University of Indonesia. Essay. University of Indonesia. Depok.

13. Milkovich, Newman, Gerhart. \{2014\}. Compensation. New York: International Ed, McGraw Hill.

14. Nusatria, Sandi and Suharnomo. \{2011\}. Employee Engagement: Antecedents and Consequences Unit Studies in CS PT. Telkom Indonesia Semarang. Essay. Diponegoro University. Semarang.

15. Pegg, Terry. \{2009\}. Creating Engagement Through Employee Benefits. Strategic HR Review, Vol. 8 Iss: 2 pp $5-12$. 
16. Rasheed, Adnan; Khan, Sanam; Ramzan, Muhammad. \{2013\}. Antecedents and Consequences of Employee Engagement: The Case of Pakistan. Journal of Business Studies Quarterly, Vol. 4 no. 4 ISSN 22152-1034.

17. Saks, M, Alan. \{2006\}. Antecedents and Consequences of Employee Engagement. Journal of Managerial Psychology, Vol. 21 Iss: 7 pp 600-619.

18. Scott, Dow and McMullen, Tom. \{2010\}. The Impact of Rewards Programs on Employee Engagement. Arizona: WorldatWork Research.

19. Setyo Riyanto (2002). Influence of Employee Commitment and Competence on Customer Satisfaction and Value Services and their impact on Customer Loyalty (A case in the Courier Services industry in Java). Dissertation, University of Padjadjaran, not published.

20. Shuck, Brad, M; Rocco, S, Tonette; Albornoz, A, Carlos. \{2010\}. Exploring Employee Engagement From The Employee Perspective: Implications for HRD. Journal of European Industrial Training, Vol. 35 No. 4 pp 300325.

21. Soemardi, P. Tresna. Climate Role In Healthy Competition Achieve National Innovation System, SMEs Strong and Poverty Alleviation. Undated.

22. Sora, Beatriz; Amparo Caballer; and Piero, Maria, Jose. $\{2010\}$. The consequences of Job Insecurity for employees: The moderator role of job dependence. International Labour Review, Vol. 149, 1 p 59-72.

23. Setyo Riyanto, Adonia, Hapzi Ali, 2017. Effect of Motivation and Job Satisfaction on the Performance of Teachers in Mentari School Bintaro (MSB). International Journal: Scholars Bulletin, ISSN 2412-9771 (Print), ISSN 2412-897X (Online), http://scholarsbulletin.com/. Volume 3, Issue 3, March 2017

24. Wijaya, Fricha, Elsa. $\{2010\}$. Effect of Job Insecurity, Employee Commitment and Job Satisfaction on Intention to Quit (Study at PT. Bank Jatim Malang Branch). Thesis. Brawijaya University. Poor.

25. Wulandari, Purwanti and Aurik, Gustomo. \{2011\}. Analysis of Effect of Total Returns to level of lecturers Engagement Bandung Institute of Technology. Journal of Technology Management, Vol. 10 no. 3 p 281-298. 